\title{
The effect of bitter gourd (Momordica charantia) ethanolic extract on inflammatory infiltrates and NF-KB activation in periodontitis
}

\author{
Aryudhi Armis*,**, Tetiana Haniastuti*** Heni Susilowati*** \\ *Dental Nursing Study Program, Health Polytechnic of the Ministry of Health of Tanjung Karang, Lampung, Indonesia \\ **Master of Dental Sciences, Faculty of Dentistry, Universitas Gadjah Mada, Yogyakarta, Indonesia \\ ***Department of Oral Biology, Faculty of Dentistry, Universitas Gadjah Mada, Yogyakarta, Indonesia \\ *JI Soekarno - Hatta No 1, Lampung, Indonesia; e-mail: drg.aryudhi@gmail.com
}

Submitted: $14^{\text {th }}$ August 2017; Revised: 31 ${ }^{\text {st }}$ May 2018; Accepted: $2^{\text {nd }}$ October 2018

\begin{abstract}
Periodontitis is a periodontal disease involving the gingiva, periodontal ligament, cementum, and alveolar bone due to an inflammatory process. Virulence factors of periodontopathogens and inflammatory responses in periodontitis can stimulate nuclear factor-kappa B (NF-kB) activity. Charantoside $\mathrm{c}$ and Momordicosides $\mathrm{g}$ in bitter gourd prevent NF-kB activation stimulated by TNF- $\alpha$ in HepG2 cells. This study aims to determine the effect of bitter gourd fruit (Momordica charantia) ethanolic extract as an anti-inflammatory substance on the level of inflammatory infiltrates and the number of cells that experience NF-kB activation in the periodontitis model. Eighty male Wistar rats were divided into 5 groups. The mandibular incisors were ligated for 14 days to induce periodontitis. Each group was given Momordica charantia extract of $500 \mathrm{mg} / \mathrm{kg} \mathrm{BW}, 250 \mathrm{mg} / \mathrm{kg} \mathrm{BW}$, and $100 \mathrm{mg} / \mathrm{kg} \mathrm{BW}$; ibuprofen $100 \mathrm{mg} / \mathrm{kg} \mathrm{BW}$; and aquades orally using oral gavage on the day 14. Rat necropsy was carried out on day 1, 3, 5, and 7 after giving the substances. Taking out the lower jaw was done to make tissue preparations followed by staining them with hematoxylin eosin (HE). Immunohistochemical analysis was performed to observe cells that were positive for NF-kB activation. The results showed a decrease in the density of inflammatory infiltrates in all groups, except for those given aquades. The number of inflammatory cells of neutrophils, macrophages, and lymphocytes that experienced NF-kB activation showed the most effective decrease in the group of Momordica charantia $500 \mathrm{mg} / \mathrm{kg} \mathrm{BW}$, on the 7th day. The conclusion of this study is that ethanolic extract of Momordica charantia has an anti-inflammatory effect and prevents the activation of NF-kB in rat gingival induced by periodontitis. The highest effect was found at a dose of $500 \mathrm{mg} / \mathrm{kg} \mathrm{BW}$ on day 7 after giving of extracts.
\end{abstract}

Keywords: bitter gourd (Momordica charantia); inflammatory infiltrates; NF-kB; periodontitis

\section{INTRODUCTION}

Periodontitis is a chronic inflammatory disease as a tissue response to periodontopathogenic bacteria that remain in gingival tissue. The response results in changes in the gingival tissue or developments causing damage to the periodontal tissue, accompanied by loss of bone attachment and damage. ${ }^{1}$ Inflammatory cells that play a role in periodontal disease include neutrophils, macrophages, and lymphocytes. ${ }^{2}$

Previous studies have shown that the causes of periodontal disease are periodontopathogenic bacteria, such as: Porphyromonas gingivalis (P. gingivalis), Aggregatibacter actinomycetemcomitans (A. Actinomicetemcomitans), Tannerella forsyithia, Prevotella nigriscens, Parvimonas micra, Fusobacterium nucleatum and Campilobacter rectus. ${ }^{3}$ Analysis results of reverse transcription polymerase chain reaction (RT-PCR) in the control group of Wistar rats induced by periodontitis using ligature yarn showed $A$. actinomicetemcomitans involvement by $36 \%$ and $P$. gingivalis by $60 \%{ }^{4}$

Nuclear factor - kappa B (NF-kB) is a transcription factor that plays an important role in the regulation of the immune system in the inflammatory process. Lipopolysaccharide (LPS) released by periodontopathogens such as $A$. actinomicetemcomitans and $P$. gingivalis in periodontitis, play an important role in NF-KB activation. When periodontopathogenic infections 
occur, these bacteria activate the NF-kB transcription factor through Toll Like Receptor (TLR) stimulation, which is expressed in nonspecific immune cells, including macrophage cells, dendritic, and mucosal epithelium. ${ }^{5}$

Bitter gourd plant (Momordica charantia) is beneficial to the health of the human body. It (Momordica charantia) can be used as traditional medicine in the treatment of several diseases, as well as in inflammatory conditions. ${ }^{6,7}$ The use of Momordica charantia in mice with a high-fat diet reduced inflammatory indicators. ${ }^{8}$ Water-ethanol extract of Momordica charantia suppressed NF-KB activity. ${ }^{9}$ The Momordica charantia also reduced levels of Prostaglandin E2 (PGE2), Interleukin $1 \beta$ (IL-1 $\beta$ ), Interleukin 6 (IL-6), Interleukin 7 (IL7), Tumor Necrosis Factor $\alpha$ (TNF $\alpha$ ), and, and increased the secretion of Transforming Growth Factor $\beta$ (TGF- $\beta$ ), Interleukin 10 (IL-10). ${ }^{7}$

The main bioactive component in the Momordica charantia, which is anti-inflammatory is the Curcubitance-type triterpen glicosides. Nhiem et al. ${ }^{7}$ conducted a study of 17 types of Curcubitance-type triterpen glicosides isolated from Momordica charantia. Of these 17 types, type 6 (Charantoside c) and type 8 (Momordicosides G) were found to prevent NF-KB activation stimulated by TNFa in HepG2 cells. ${ }^{7}$ The purpose of this study is is to determine the effect of ethanolic extract of bitter gourd fruit (Momordica charantia) as an anti-inflammatory substance by analyzing density levels of inflammatory infiltrate and number of cells undergoing NF-KB activation in the Wistar rats' periodontitis model.

\section{MATERIALS AND METHODS}

All research procedures have been approved by the ethics committee of the Faculty of Dentistry, Universitas Gadjah Mada, Yogyakarta with the issuance of number ethical clearance clearance certificate No: 00768/KKEP/FKG-UGM/EC/2016. Eighty male Wistar rats were divided into 5 groups, each group consisted of 4 rats on each observation day $(1,3,5$, and 7 days after treatment).

Before the induction of periodontitis, the mice were anesthetized using ketamine $\mathrm{HCl} 1 \mathrm{ml} / \mathrm{kg} \mathrm{BW}$ on the intramuscular. The induction of periodontitis in mice was was done by wrapping a ligature from silk (silk ligature) size 3.0 around the bottom edge of the lower gingiva of the mandibular anterior incisor. ${ }^{10}$ Ligation was checked every day until the 14th day of attachment. On the 15th day, each group was given Momordica charantia extract of of $500 \mathrm{mg} / \mathrm{kg}$ BW, $250 \mathrm{mg} / \mathrm{kg} \mathrm{BW}$, and $100 \mathrm{mg} / \mathrm{kg} \mathrm{BW}$, ibuprofen $100 \mathrm{mg} / \mathrm{kg} \mathrm{BW}$, and aquades. The administration of Momordica charantia extract, ibuprofen, and aquades was done orally using $5 \mathrm{~mL}$ of oral gavage 3 times a day. Rats were sacrificed on days 1, 3, 5, and 7 after treatment with anesthesia over intramuscular dose of ketamine $\mathrm{HCl}$. The lower jaw was was taken out for making tissue preparations.

The mandible was fixated with $10 \%$ formalin buffer solution and decalcified using 10\% EDTA $\mathrm{pH} 7.4$ for 30 days. The samples were were then dehydrated by soaking them in multilevel alcohol, followed by a purifying substance. They were inserted into liquid paraffin to make blocks. The position of the samples was was arranged in such a way so that when it was was cut, it would obtain longitudinal pieces. Next, the paraffin block was cut into $4 \mu \mathrm{m}$ thick with a microtome to be stained using $\mathrm{HE}$ and as thick as $5 \mu \mathrm{m}$ to be stained with immunohistochemical anti-NF$\mathrm{kB}$ mouse monoclonal antibody NF-kB and IgG as the secondary antibody. The observation of inflammatory infiltration density was carried out by assessing 10 fields of view in the epithelial layer and gingival sulcus connective tissue based on the following parameters: "Absent", if in 10 fields, the field of view did not show the presence of inflammatory cells; "low", if there were at least 5 fields showing infiltrates of inflammatory cells that occupied $<50 \%$ of the field of view; "moderate", if there were at least 5 fields showing infiltrates of inflammatory cells that occupied $>50 \%$ of the field of view; and "dense", if all (10) fields evaluated showed an inflammatory cephalic infiltrate occupying $>90 \%$ of the field of view. ${ }^{11}$ Rating of the number of cells undergoing NF-KB activation was carried out by calculating the number of inflammatory infiltrate cells experiencing NF-KB that was was brown color on the cell nucleus. The observations were made 
on 2 view fields, namely the base of gingival sulcus and gingival connective tissue.

The data of inflammatory infiltrate density were ordinal. Furthermore, the data were tested by the Kruskal Wallis test and with the Mann Whitney post hoc test. Data on the number of cells that experience NF-kB activation were nominal. The data were tested by a two-way analysis of variance (ANOVA) followed by a post-hoc LSD test.

\section{RESULTS}

The results showed that the density level inflammatory cell infiltrates in all treatment groups decreased over time, except in the group of rats which were only given aquades. This indicates that the inflammatory process decreases with the administration of ethanolic extract of Momordica charantia and ibuprofen (Table 1).

Table 1. Level of inflammatory infiltrates in the five treatment groups during the observation period (Days $1,3,5,7$ )

\begin{tabular}{|c|c|c|c|c|c|}
\hline Group & Density & Day 1 & Day 3 & Day 5 & Day 7 \\
\hline \multirow{3}{*}{$\begin{array}{l}\text { Momordica } \\
\text { charantia } \\
\text { extract } \\
500 \mathrm{mg} / \mathrm{kg} \mathrm{BW}\end{array}$} & Low & $0(0 \%)$ & $1(25 \%)$ & $3(75 \%)$ & $4(100 \%)$ \\
\hline & Moderate & $1(25 \%)$ & $2(50 \%)$ & $1(25 \%)$ & $0(0 \%)$ \\
\hline & Dense & $3(75 \%)$ & $1(25 \%)$ & $0(0 \%)$ & $0(0 \%)$ \\
\hline \multirow{3}{*}{$\begin{array}{l}\text { Bitter gourd } \\
\text { extract } \\
250 \mathrm{mg} / \mathrm{kg} \mathrm{BW}\end{array}$} & Low & $0(0 \%)$ & $1(25 \%)$ & $3(75 \%)$ & $3(75 \%)$ \\
\hline & Moderate & $1(25 \%)$ & $2(50 \%)$ & $1(25 \%)$ & $1(25 \%)$ \\
\hline & Dense & $3(75 \%)$ & $1(25 \%)$ & $0(0 \%)$ & $0(0 \%)$ \\
\hline \multirow{3}{*}{$\begin{array}{l}\text { Bitter gourd } \\
\text { extract } \\
100 \mathrm{mg} / \mathrm{kg} \mathrm{BW}\end{array}$} & Low & $0(0 \%)$ & $0(0 \%)$ & $1(25 \%)$ & $3(75 \%)$ \\
\hline & Moderate & $2(50 \%)$ & $3(75 \%)$ & $3(75 \%)$ & $1(25 \%)$ \\
\hline & Dense & $2(50 \%)$ & $1(25 \%)$ & $0(0 \%)$ & $0(0 \%)$ \\
\hline \multirow{3}{*}{$\begin{array}{l}\text { Ibuprofen } 100 \\
\mathrm{mg} / \mathrm{kg} \mathrm{BW}\end{array}$} & Low & $0(0 \%)$ & $1(25 \%)$ & $3(75 \%)$ & $3(75 \%)$ \\
\hline & Moderate & $2(50 \%)$ & $3(75 \%)$ & $1(25 \%)$ & $1(25 \%)$ \\
\hline & Dense & $2(50 \%)$ & $0(0 \%)$ & $0(0 \%)$ & $0(0 \%)$ \\
\hline \multirow{3}{*}{ Aquades } & Low & $0(0 \%)$ & $0(0 \%)$ & $0(0 \%)$ & $0(0 \%)$ \\
\hline & Moderate & $1(25 \%)$ & $1(25 \%)$ & $1(25 \%)$ & $1(25 \%)$ \\
\hline & Dense & $3(75 \%)$ & $3(75 \%)$ & $3(75 \%)$ & $3(75 \%)$ \\
\hline
\end{tabular}

Table 2. Kruskal Wallis test results for the density of inflammatory infiltrates in the five treatment groups during the observation period (days $1,3,5,7$ )

\begin{tabular}{|c|c|c|c|c|c|c|c|c|}
\hline \multirow[b]{2}{*}{ Group } & \multicolumn{2}{|c|}{ Day 1} & \multicolumn{2}{|c|}{ Day 3} & \multicolumn{2}{|c|}{ Day 5} & \multicolumn{2}{|c|}{ Day 7} \\
\hline & $\begin{array}{l}\text { Mean } \\
\text { rank }\end{array}$ & $\mathrm{p}$ & $\begin{array}{l}\text { Mean } \\
\text { rank }\end{array}$ & $\mathrm{p}$ & $\begin{array}{l}\text { Mean } \\
\text { rank }\end{array}$ & $\mathrm{p}$ & $\begin{array}{l}\text { Mean } \\
\text { rank }\end{array}$ & $p$ \\
\hline $\begin{array}{l}\text { Momordica } \\
\text { charantia extract } \\
500 \mathrm{mg} / \mathrm{kg} \mathrm{BW}\end{array}$ & 11.50 & & 9.38 & & 7.63 & & 7.00 & \\
\hline $\begin{array}{l}\text { Momordica } \\
\text { charantia extract }\end{array}$ & 11.50 & & 9.38 & & 7.63 & & 9.13 & \\
\hline Momordica & & 0.87 & & 0.26 & & $0.03^{*}$ & & $0.02^{*}$ \\
\hline $\begin{array}{l}\text { charantia extract } \\
100 \mathrm{mg} / \mathrm{kg} \mathrm{BW}\end{array}$ & 9.00 & & 11.13 & & 11.88 & & 9.13 & \\
\hline $\begin{array}{l}\text { Ibuprofen } 100 \\
\mathrm{mg} / \mathrm{kg} \mathrm{BW}\end{array}$ & 9.00 & & 7.25 & & 7.63 & & 9.13 & \\
\hline Aquades & 11.50 & & 15.38 & & 17.75 & & 18.13 & \\
\hline
\end{tabular}

Description: * significantly different at $p<0.05$ 
Table 3. Mann Whitney post hoc density level of inflammatory infiltrates in the five treatment groups on day 5 and 7

\begin{tabular}{|c|c|c|}
\hline \multirow{2}{*}{ Group } & \multicolumn{2}{|c|}{$\mathrm{p}$ value } \\
\hline & Day 5 & Day 7 \\
\hline Momordica charantia extract $500 \mathrm{mg} / \mathrm{kg} \mathrm{BW}-250 \mathrm{mg} / \mathrm{kg}$ BW & 1.00 & 0.32 \\
\hline Momordica charantia extract 500 mg/kg BW- 100 mg/kg BW & 0.19 & 0.32 \\
\hline Momordica charantia extract 500 mg/kg BW-Ibuprofen 100 mg/kg BW & 1.00 & 0.32 \\
\hline Momordica charantia extract 500 mg/kg BW-Aquades & $0.02 *$ & $0.01^{*}$ \\
\hline Momordica charantia extract $250 \mathrm{mg} / \mathrm{kg}$ BW-100 mg/kg BW & 0.19 & 1.00 \\
\hline Momordica charantia extract $250 \mathrm{mg} / \mathrm{kg}$ BW-Ibuprofen $100 \mathrm{mg} / \mathrm{kg} \mathrm{BW}$ & 1.00 & 1.00 \\
\hline Momordica charantia extract $250 \mathrm{mg} / \mathrm{kg}$ BW-Aquades & $0.02 *$ & $0.02 *$ \\
\hline Momordica charantia extract 100 mg/kg BW-Ibuprofen 100 mg/kg BW & 0.19 & 1.00 \\
\hline Momordica charantia extract 100 mg/kg BW-Aquades & $0.04^{*}$ & $0.02 *$ \\
\hline Ibuprofen 100 mg/kg BW-Aquades & $0.02^{*}$ & $0.02 *$ \\
\hline
\end{tabular}

Description: * significantly different at $p<0.05$

Table 4. Kruskal Wallis test results of of inflammatory infiltrate density levels during observation days (day 1, 3, 5, and 7) in each group

\begin{tabular}{|c|c|c|c|c|c|c|c|c|c|c|}
\hline \multirow[t]{2}{*}{ Day } & \multicolumn{2}{|c|}{$\begin{array}{l}\text { Momordica } \\
\text { charantia extract } \\
500 \text { mg/kg BW }\end{array}$} & \multicolumn{2}{|c|}{$\begin{array}{l}\text { Momordica } \\
\text { charantia extract } \\
250 \mathrm{mg} / \mathrm{kg} \mathrm{BW}\end{array}$} & \multicolumn{2}{|c|}{$\begin{array}{l}\text { Momordica } \\
\text { charantia extract } \\
100 \mathrm{mg} / \mathrm{kg} \mathrm{BW}\end{array}$} & \multicolumn{2}{|c|}{$\begin{array}{l}\text { Ibuprofen } \\
100 \text { mg/kg BW }\end{array}$} & \multicolumn{2}{|c|}{ Aquades } \\
\hline & $\begin{array}{l}\text { Mean } \\
\text { rank }\end{array}$ & $p$ & $\begin{array}{l}\text { Mean } \\
\text { rank }\end{array}$ & $p$ & $\begin{array}{l}\text { Mean } \\
\text { rank }\end{array}$ & $p$ & $\begin{array}{l}\text { Mean } \\
\text { rank }\end{array}$ & $p$ & $\begin{array}{l}\text { Mean } \\
\text { rank }\end{array}$ & $p$ \\
\hline Day 1 & 13.50 & & 13.38 & & 12.00 & & 13.25 & & 8.50 & \\
\hline Day 3 & 10.00 & $0.02^{*}$ & 9.63 & $0.03^{*}$ & 10.50 & $0.04^{*}$ & 9.25 & $0.04^{*}$ & 8.50 & 1.00 \\
\hline Day 5 & 6.00 & & 5.50 & & 7.38 & & 5.75 & & 8.50 & \\
\hline Day 7 & 4.50 & & 5.50 & & 4.13 & & 5.75 & & 8.50 & \\
\hline
\end{tabular}

Description: * significantly different at $p<0.05$

Table 5. The results of the Mann Whitney post hoc test of the density level of the inflammatory infiltrate between the observation days in each treatment group

\begin{tabular}{cccccc}
\hline & \multicolumn{5}{c}{ p value } \\
\cline { 2 - 6 } Day & & $\begin{array}{l}\text { Momordica } \\
\text { charantia extract } \\
250 \mathrm{mg} / \mathrm{kg} \mathrm{BW}\end{array}$ & $\begin{array}{l}\text { Momordica } \\
\text { charantia extract } \\
100 \mathrm{mg} / \mathrm{kg} \mathrm{BW}\end{array}$ & $\begin{array}{l}\text { Ibuprofen } \\
100 \mathrm{mg} / \mathrm{kg} \mathrm{BW}\end{array}$ & Aquades \\
\hline Day 1-3 & 0.16 & 0.16 & 0.50 & $0.01^{*}$ & 1.00 \\
Day 1-5 & $0.02^{*}$ & $0.02^{*}$ & $0.01^{*}$ & $0.03^{*}$ & 1.00 \\
Day 1-7 & $0.01^{*}$ & $0.02^{*}$ & $0.03^{*}$ & $0.03^{*}$ & 1.00 \\
Day 3-5 & 0.156 & 0.16 & 0.19 & 0.19 & 1.00 \\
Day 3-7 & $0.04^{*}$ & 0.16 & $0.04^{*}$ & 0.19 & 1.00 \\
Day 5-7 & 0.32 & 1.00 & 0.19 & 1.00 & 1.00 \\
\hline
\end{tabular}

Description: * significantly different at $p<0.05$

The test results of the data analysis in Table 2 with Kruskal Wallis show a value of $p>0.05$ on day 1 and 3 , whereas on days 5 and $7 p$ was $<0.05$. This means that the density of inflammatory infiltrate differed significantly on days 5 and 7 in various groups.

The results of Mann-Whitney post-hoc test on the 5th and 7 th day showed that there were significant differences in inflammatory density between groups of various concentrations of Momordica charantia extract and aquades, and between ibuprofen $100 \mathrm{mg} / \mathrm{kg}$ BW with aquades $(p<0.05)$, whereas the the groups of various concentrations of Momordica charantia extract and ibuprofen $100 \mathrm{mg} / \mathrm{kg}$ BW showed no significant differences $(p>0.05)$. This indicates that after the 
administration of ethanolic extract of Momordica charantia, the density of inflammatory infiltrate on days 5 and 7 was significantly different when compared to aquades, but not significantly different when compared to ibuprofen. Thus, it can be interpreted that the effect of giving Momordica charantia is the same as ibuprofen as a positive control (Table 3).

The density of the inflammatory infiltrate decreased from the initial observation (day 1) to the end of observation (day 7) in all groups, except aquades. Analysis of differences in the density of inflammatory infiltrates based on observation days in each group was carried out using the Kruskal Wallis test. The Kruskal Wallis test results in Table 4 show significant values $(p<0.05)$ in all groups, except for aquades groups $(p=1.00)$. This means that the density of inflammatory infiltrates is significantly different from the beginning to the end of the observation, except in the aquades group.

The Mann Whitney post hoc test as presented in Table 5 shows that there are significant differences $(p<0.05)$ between the Momordica charantia group of $500 \mathrm{mg} / \mathrm{kg} \mathrm{BW}, 250 \mathrm{mg} / \mathrm{kg} \mathrm{BW}, 100 \mathrm{mg} / \mathrm{kg} \mathrm{BW}$ and ibuprofen $100 \mathrm{mg} / \mathrm{kg} \mathrm{BW}$ on day 1 with 5 , and day 1 with 7 . This means that a significant decrease in the density of inflammatory infiltrate occurs at 5 days after giving Momordica charantia extract of of $500 \mathrm{mg} / \mathrm{kg} \mathrm{BW}, 250 \mathrm{mg} / \mathrm{kg} \mathrm{BW}, 100 \mathrm{mg} / \mathrm{kg} \mathrm{BW}$ and ibuprofen $100 \mathrm{mg} / \mathrm{kg}$ BW. A significant decrease in the density of inflammatory infiltrates was found in the ibuprofen group of of $100 \mathrm{mg} / \mathrm{kg}$ BW on day 1 with 3, and the Momordica charantia group $500 \mathrm{mg} /$ $\mathrm{kg} \mathrm{BW}$ and $100 \mathrm{mg} / \mathrm{kg} \mathrm{BW}$ on day 3 with 7 . While in group of of $250 \mathrm{mg} / \mathrm{kg} \mathrm{BW}$ and $100 \mathrm{mg} / \mathrm{kg} \mathrm{BW}$, there was no significant difference $(p>0.05)$. This highlight that in this group there was no decrease in the density of inflammatory infiltrates during the observation period.

The observation of the number of activated NF-KB cells showed a decrease with increasing observation days in the group of periodontitis rats treated with Momordica charantia extract of $500 \mathrm{mg} / \mathrm{kg} \mathrm{BW}, 250 \mathrm{mg} / \mathrm{kg}$ BW, $100 \mathrm{mg} / \mathrm{kg}$ BW, ibuprofen, and aquades. The group of rats given the Momordica charantia fruit ethanolic extract of $500 \mathrm{mg} / \mathrm{kg}$ BW showed the least number of cells with activated NF-KB compared to the other groups. The group of rats given the ethanolic extract of Momordica charantia of $250 \mathrm{mg} / \mathrm{kg}$ BW showed a greater number of NF-KB cells compared to the group that received $500 \mathrm{mg} / \mathrm{kg}$ BW of Momordica charantia extract, but less than group with $100 \mathrm{mg} /$ $\mathrm{kg}$ BW. The group of rats given ibuprofen of 100 $\mathrm{mg} / \mathrm{kg}$ BW showed the number of cells with NF$K B$ activation which was almost the same as the group of rats given $100 \mathrm{mg} / \mathrm{kg}$ BW of Momordica charantia ethanolic extract. This shows that the higher the concentration of Momordica charantia ethanolic extract given, the less the number of cells that experience NF-KB activation (Figure 1,2).

The two-way ANOVA test results in Table 6 indicate that there were differences in the number of inflammatory cells that experienced NF-KB

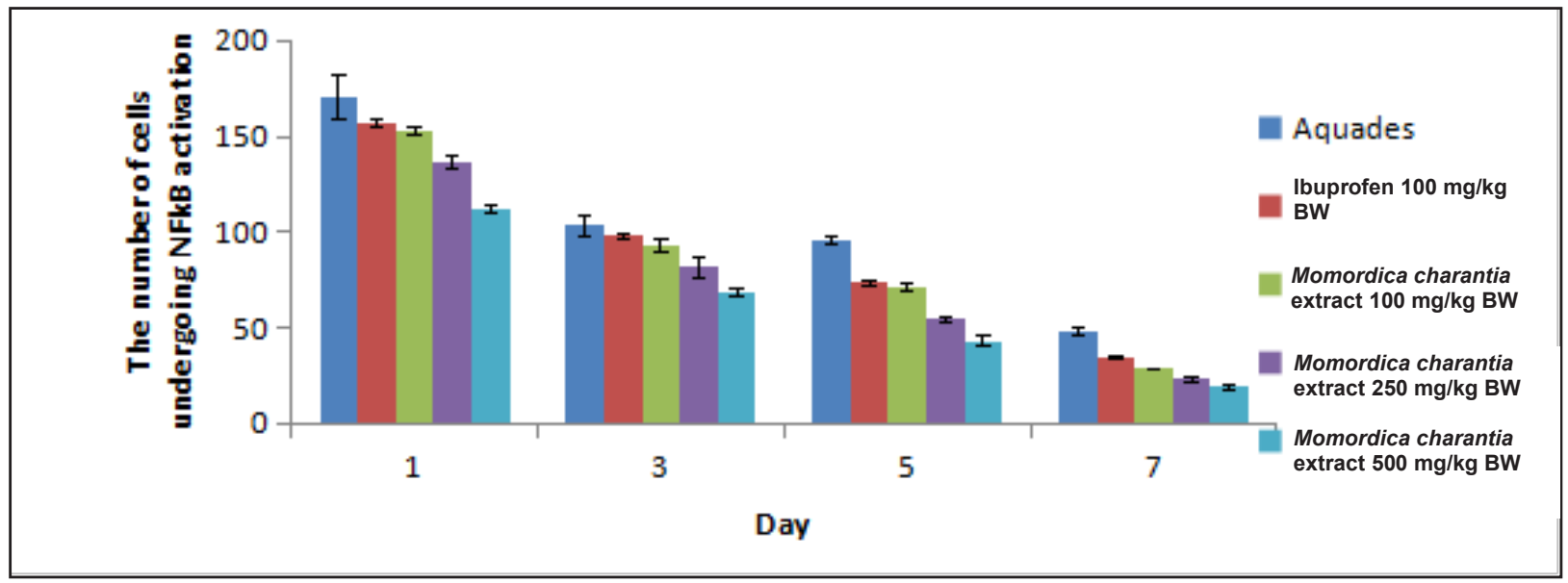

Figure 1. Number of inflammatory cells that have NF-KB activation in 5 treatment groups during the observation period 


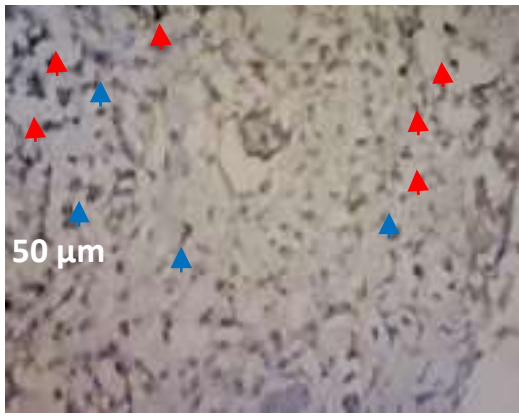

(A)

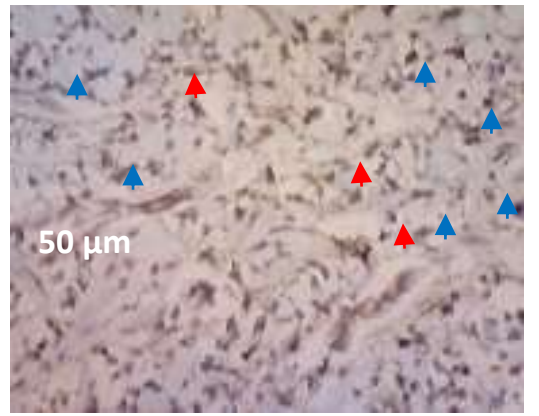

(B)

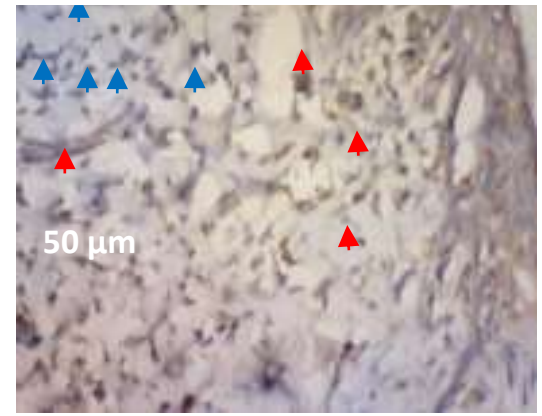

(C)

Figure 2. Immunohistochemical features of inflammatory cells that experience activation of NF-KB p50 rat gingival tissue on day 7 are shown by arrows (red), while those with arrows (blue) are for are for. (A) Aquades group; (B) bitter gourd extract of of 500 $\mathrm{mg} / \mathrm{kg} \mathrm{BB}$; (C) ibuprofen $100 \mathrm{mg} / \mathrm{kg}$ BB

activation which were significant $(p<0.05)$ between groups, days of observation, and interactions between treatment groups and observation days. This means that the day of observation and treatment has a significant effect on the number of inflammatory cells that undergo NF-kB activation.

To compare the differences between treatment groups, a post hoc LSD test was done and can be seen in Table 7. The results of the post hoc LSD test in Table 7 show that there are significant differences in the number of cells that experienced NF-KB activation between treatment groups during the observation day $(p<0.05)$, except the Momordica charantia extract group of of $100 \mathrm{mg} / \mathrm{kg}$ BW with $100 \mathrm{mg} / \mathrm{kg} \mathrm{BW}$ ibuprofen on day 1 and 3 , and Momordica charantia extract group with $250 \mathrm{mg} /$ $\mathrm{kg} \mathrm{BW}$ and $100 \mathrm{mg} / \mathrm{kg} \mathrm{BW}$ on day 7 ( $p>0.05$ ). This shows that the number of cells undergoing NF-KB activation between treatment groups experienced a statistically significant decrease, except for the group of Momordica charantia of $100 \mathrm{mg} / \mathrm{kg}$ compared to ibuprofen of of $100 \mathrm{mg} / \mathrm{kg}$ BW on days 1 and 3 , and Momordica charantia group of $250 \mathrm{mg} /$ $\mathrm{kg} \mathrm{BW}$ and $100 \mathrm{mg} / \mathrm{kg} \mathrm{BW}$ on day 7 .

The results of the post hoc LSD test in Table 8 show that there are significant differences in the number of cells that experienced NF-KB activation between the observation days in each group, which is indicated by the value $(p<0.05)$. Thus, it can be concluded that the average number of cells experiencing NF-KB activation showed a significant decrease over time in various treatment groups.

Table 6. The summary of two-way ANOVA test results for the number of inflammatory cells that undergo NF-KB activation

\begin{tabular}{lll}
\hline Source & $\mathrm{F}$ & $\mathrm{p}$ value \\
\hline Group & 348.03 & $0.00^{*}$ \\
Day & 3630.29 & $0.00^{*}$ \\
Group-day & 12.31 & $0.00^{*}$ \\
\hline
\end{tabular}

Description: * significantly different at $p<0.05$

Table 7. Post hoc LSD test results for the number of inflammatory cells that experienced NF-KB activation between treatment groups

\begin{tabular}{lllll}
\hline \multicolumn{1}{c}{ Group } & \multicolumn{3}{c}{ p value } \\
\cline { 2 - 5 } & Day 1 & Day 3 & Day 5 & Day 7 \\
\hline Momordica charantia extract of of $500 \mathrm{mg} / \mathrm{kg}$ - $250 \mathrm{mg} / \mathrm{kg}$ & $0.00^{*}$ & $0.00^{*}$ & $0.00^{*}$ & $0.00^{*}$ \\
Momordica charantia extract of of $500 \mathrm{mg} / \mathrm{kg}$ - $100 \mathrm{mg} / \mathrm{kg}$ & $0.00^{*}$ & $0.00^{*}$ & $0.00^{*}$ & $0.00^{*}$ \\
Momordica charantia extract of of $500 \mathrm{mg} / \mathrm{kg}$ - ibuprofen $100 \mathrm{mg} / \mathrm{kg}$ & $0.00^{*}$ & $0.00^{*}$ & $0.00^{*}$ & $0.00^{*}$ \\
Momordica charantia extract of of $500 \mathrm{mg} / \mathrm{kg}$ - aquades & $0.00^{*}$ & $0.00^{*}$ & $0.00^{*}$ & $0.00^{*}$ \\
Momordica charantia extract of of $250 \mathrm{mg} / \mathrm{kg}$ - $100 \mathrm{mg} / \mathrm{kg}$ & $0.00^{*}$ & $0.00^{*}$ & $0.00^{*}$ & 0.05 \\
Momordica charantia extract of of $250 \mathrm{mg} / \mathrm{kg}$ - ibuprofen $100 \mathrm{mg} / \mathrm{kg}$ & $0.00^{*}$ & $0.00^{*}$ & $0.00^{*}$ & $0.00^{*}$ \\
Momordica charantia extract of of $250 \mathrm{mg} / \mathrm{kg}$ - aquades & $0.00^{*}$ & $0.00^{*}$ & $0.00^{*}$ & $0.00^{*}$ \\
Momordica charantia extract of of $100 \mathrm{mg} / \mathrm{kg}$ - ibuprofen $100 \mathrm{mg} / \mathrm{kg}$ & 0.24 & 0.33 & $0.02^{*}$ & $0.02^{*}$ \\
Momordica charantia extract of of $100 \mathrm{mg} / \mathrm{kg}$ - aquades & $0.00^{*}$ & $0.00^{*}$ & $0.00^{*}$ & $0.00^{*}$ \\
Ibuprofen of of 100 mg/kg- aquades & $0.00^{*}$ & $0.03^{*}$ & $0.00^{*}$ & $0.00^{*}$ \\
\hline
\end{tabular}

Description: * significantly different at $p<0.05$ 
Majalah Kedokteran Gigi Indonesia. April 2019; 5(1): 6 - 14

ISSN 2460-0164 (print)

ISSN 2442-2576 (online)

Table 8. Results of the post hoc LSD number of inflammatory cells that undergo NF-KB activation between observation days

\begin{tabular}{|c|c|c|c|c|c|}
\hline \multirow[b]{2}{*}{ Day } & \multicolumn{5}{|c|}{ p value } \\
\hline & $\begin{array}{c}\text { Momordica charantia } \\
\text { extract } \\
500 \mathrm{mg} / \mathrm{kg}\end{array}$ & $\begin{array}{c}\text { Momordica } \\
\text { charantia extract } \\
250 \mathrm{mg} / \mathrm{kg}\end{array}$ & $\begin{array}{c}\text { Momordica } \\
\text { charantia extract } \\
100 \mathrm{mg} / \mathrm{kg}\end{array}$ & $\begin{array}{l}\text { Ibuprofen } \\
100 \mathrm{mg} / \mathrm{kg}\end{array}$ & Aquades \\
\hline Day 1-3 & $0.00^{*}$ & $0.00^{*}$ & $0.00^{*}$ & $0.00^{*}$ & $0.00^{*}$ \\
\hline Day 1-5 & $0.00^{*}$ & $0.00^{*}$ & $0.00^{*}$ & $0.00^{*}$ & $0.00^{*}$ \\
\hline Day 1-7 & $0.00^{*}$ & $0.00^{*}$ & $0.00^{*}$ & $0.00^{*}$ & $0.00^{*}$ \\
\hline Day 3-5 & $0.00^{*}$ & $0.00^{*}$ & $0.00^{*}$ & $0.00^{*}$ & $0.02^{*}$ \\
\hline Day 3-7 & $0.00^{*}$ & $0.00^{*}$ & $0.00^{*}$ & $0.00^{*}$ & $0.00^{*}$ \\
\hline Day 5-7 & $0.00^{*}$ & $0.00^{*}$ & $0.00^{*}$ & $0.00^{*}$ & $0.00^{*}$ \\
\hline
\end{tabular}

Description: * significantly different at $p<0.05$

The two-way ANOVA test results in Table 6 showed that there were significant differences $(p<0.05)$ of the number of inflammatory cells activated by NF-kB between groups, observation days and interactions between treatment groups and observation days. This means that the day of observation and treatment has a significant effect on the number of inflammatory cells undergoing NF-KB activation. To compare between treatment groups continued with LSD post hoc test which can be seen in Table 7, while to compare between days of observation can be seen in Table 8 .

The post hoc LSD test results in Table 7 show that the number of cells undergoing NF-KB activation between treatment groups experienced a statistically significant decrease, except for the bitter melon group $100 \mathrm{mg} / \mathrm{kg}$ BW compared with ibuprofen $100 \mathrm{mg} / \mathrm{kg} \mathrm{BW}$ on day 1 and 3rd, and bitter melon group $250 \mathrm{mg} / \mathrm{kg}$ BW with bitter melon $100 \mathrm{mg} / \mathrm{kg} \mathrm{BW}$ on the 7th day. The post hoc LSD test results in Table 8 show that there is a significant difference in the number of cells undergoing NF$\mathrm{KB}$ activation between days of observation in each group, which is indicated by $p$ values $<0.05$.

\section{DISCUSSION}

Periodontitis is an infectious disease caused by interactions between periodontopathogenic bacteria and the body's immune system, which is characterized by junctional epithelium migration to the apical, loss of connective tissue attachment, and damage of periodontal ligament and alveolar bone. Induction of periodontitis in this study was obtained by insertion of of silk ligature diameter of of 3.0 around the rats' mandibular incisor. ${ }^{12}$ After silk ligature insertion for 14 days, rats' gingiva showed a clinical changes in the form of reddish discoloration, bleeding, edema, and gingival recession which is clinical signs of periodontitis. Insertion of ligation can trigger plaque accumulation and micro ulceration in the sulcular epithelium. ${ }^{13}$

Inflammation is the body's defense response involving host cells, blood vessels, proteins, and several mediators that aim to eliminate the cause of cell damage and begin the healing process. Pathological conditions in the inflammatory process are characterized by the release of inflammatory mediators by inflammatory cells, causing tissue damage. ${ }^{14}$ The release of inflammatory mediators is regulated by NF-KB which acts as a transcription factor. Activators of NF-kB such as LPS, TNFa, and $\mathrm{IL}-1 \beta$ are often found in people with periodontitis. These molecules are responsible for the immune and inflammatory responses that cause damage to soft tissue and bone in the development of periodontitis. $^{15}$

The cells that were activated by NF-kB on the 1st day of observation were found in large numbers in all treatment groups. This is thought to be bacterial invasion and LPS in the tissue causing $\mathrm{NF}-\mathrm{kB}$ activation in the gingival sulcus epithelial cells and subsequently increasing the secretion of cytokines in the activation of inflammatory cells. ${ }^{14}$ The number of cells undergoing NF-KB activation 
have decreased over time. This might be due to due to Charantoside $\mathrm{c}$ and Momordicoside $\mathrm{g}$ contained in Momordica charantia that that prevent NF-KB activation stimulated by TNF $\alpha .{ }^{7}$ If NF-KB activation is prevented, the level of inflammatory mediators in the tissue will decrease. ${ }^{8}$

The density level of inflammatory infiltrates in all observation groups showed a decrease during the observation period, except for the aquades group. The number of cells undergoing NF-KB activation has decreased during the observation day and this phenomenon occurs in all groups. This is likely to occur because the inflammatory molecular biology process decreases in response to the administration of ethanolic extract of Momordica charantia fruit as an anti-inflammatory substance. The results of this study are corresponding with the research conducted by Chao et al. done to sepsis rats. The study showed that administration of bitter gourd (Momordica charantia) in sepsis rats resulted in expression decrease of COX-2 protein, iNOS, $\mathrm{NF}-\mathrm{KB}$, and inflammatory responses during the observation period. ${ }^{8}$

The anti-inflammatory effectiveness of ethanolic extract of Momordica charantia $500 \mathrm{mg} / \mathrm{kg}$ BW is the best compared to the ethanolic extract of bitter gourd fruit $250 \mathrm{mg} / \mathrm{kg} \mathrm{BW}, 100 \mathrm{mg} / \mathrm{kg} \mathrm{BW}$, and ibuprofen $100 \mathrm{mg} / \mathrm{kg} \mathrm{BW}$. The results of this study are corresponding with the research conducted by Ullah $\mathrm{M}$ et al, which showed that the administration of ethanolic extract of bitter gourd with $500 \mathrm{mg} /$ kg BW had an anti-inflammatory effect better than that of the smaller doses. ${ }^{16}$ It is possiblyy due to the greater number of active substances acting as anti-inflammatory agents. Thus, the administration of ethanolic extract of Momardica charantia of of $500 \mathrm{mg} / \mathrm{kg} \mathrm{BW}$ is is recommended as an antiinflammatory substance in periodontitis. The use of the ethanolic extract of the Momordica charantia until a dose of $2000 \mathrm{mg} / \mathrm{kg}$ BW has no toxic effects and behavior changes, so it is is considered a safe herbal of of anti-inflammatory drug. ${ }^{16}$

Ibuprofen as an anti-inflammatory has several effects, such as preventing PGE2 synthesis, leukocyte function, suppressing migration of neutrophils and IFN- $\gamma$ stimulated macrophages, decreasing levels of NF-KB, I-KB, and $\mathrm{kB}$ kinase (IKK) inhibitors. The results of the study showed that after giving ibuprofen of of $100 \mathrm{mg} / \mathrm{kg} \mathrm{BW}$, the density of inflammatory infiltrates decreased over time. This is in accordance with the research conducted by Rainsford KD, that ibuprofen can reduce levels of IL-1 $\beta$ and IL- 6 on the results of microsrodialysis after administration of $800 \mathrm{mg}$ ibuprofen. ${ }^{17}$

\section{CONCLUSION}

Giving ethanolic extract of Momordica charantia decreases the density of inflammatory infiltrates, and prevents the activation of NF-KB in rats' gingiva inflected by periodontitis. The most effective concentration of ethanolic extract of Momordica charantia fruit that has an anti-inflammatory effect is $500 \mathrm{mg} / \mathrm{kg} \mathrm{BW}$. The best anti-inflammatory effect was found on the 7 th day.

\section{REFERENCES}

1. Mariano FS, Sardi JCO, Doque C, Hofling JF, Goncalves RB. The role of immune system in the development of periodontal disease: a brief review. Rev odonto ciência. 2010; 25(3): 300-305. doi: 10.1590/S1980-65232010000300016

2. Bascones A, Gamonal J, Gomes M, Silva A, Gonzales MA. New knowledge of the pathogenesis of periodontal disease. Quintessence Int. 2004; 35(9): 706-716.

3. Carranza FA, Takey HH, Newman MG. Carranza's Clinical Periodontology. $9^{\text {th }}$ ed. WB. Sounders Co. USA; 2006. 97.

4. Pimentel SP, Barella GE, Casarin RCV, Cirano FR, Casati MZ, Foglio MA, Figuera GM, Ribeiro FV. Protective effect of topical Cordia verbenaceain a rat periodontitis model: immune-inflammatory. Antibacterial and Morphometric Assays. BMC Complement Altern Med. 2012; 12: 224. doi: 10.1186/1472-6882-12-224

5. Prahasanti C. Immunohistochemical analysis of NF-kB (p50/p65) in patient with aggressive and chronic periodontitis. Indonesian Journal of Tropical Infectious Desease. 2013; 4(4): 59-64. doi: 10.20473/ijtid.v4i4.235 
6. Sharma S, Tandon S, Semwal B, Singh K. Momordica charantia Linn.: a comprehensive review on bitter remedy. Journal of Pharmaceutical Research and Opinion. 2011; 1(2): $42-47$.

7. Nhiem NX, Yen PH, Ngan NT, Quang TH, Kiem PV, Minh CV, Tai BH, Cuong NX, Song $\mathrm{SB}, \mathrm{Kim} \mathrm{YH}$. Inhibition of nuclear transcription factor-kb and activation of peroxisome proliferator-activated receptors in HepG2 cellsby cucurbitane-type triterpene glycosides from momordica charantia. J Med Food. 2012; 15(4): 369-377. doi: 10.1089/jmf.2011.1766

8. Chao CY, Sung PJ, Wang WH, Kuo YH. AntiInflammatory effect of momordica charantia in sepsis mice. Molecules. 2014; 19(8): 12777-12788. doi:10.3390/molecules190812777

9. Kim K, Kim HY. Bitter melon (Momordica charantia) extract suppresses cytokine induced activation of MAPK and NF-KB in pancreatic $\beta$-Cells. Food Sci. Biotech. 2011; 20(2): 531-535. doi: 10.1007/s10068-011-0074-x

10. Ionel $A$, Lucaciu O, Moga M, Buhatel D, llea A, Tabaran F, Catoi C, Berce C, Toader S, Campian RS. Periodontal disease induced in wistar rats - experimental study, human \& veterinary medicine. International Journal of the Bioflux Society. 2015; 7(2): 90-95.

11. Gontiya G, Galgali SR. Effect of hyaluronan on periodontitis: a clinical and histological study. J Indian Soc Periodontol. 2012; 16(2): 184-192. doi: 10.4103/0972-124X.99260
12. Praptiwi $\mathrm{H}$. Inokulasi bakteri dan pemasangan cincin atau ligatur untuk induksi periodontitis pada tikus. Majalah Kedokteran Gigi. 2008; 15(1): 81-84.

13. Graves DT, Kang J, Andriankaja O, Wada $\mathrm{K}$, Rosa Jr C. Animal models to study hostbacteria interactions involved in periodontitis. Front Oral Biol. 2012; 15: 117-132. doi: 10.1159/000329675

14. Gehrig JSN, Wilman DE. Foundations of Periodontics for the Dental Hygienist. $3^{\text {rd }}$ ed. Philadelphia: Wolters Kluwer Health, Lippincott Williams \& Wilkins; 2010. 87-89.

15. Arabaci $T$, Cicek $Y$, Canakci V, Canakci CF, Ozgoz M, Albayrak M, Keles ON. Immunohistochemical and stereologic analysis of NF-KB Activation in chronic periodontitis. Eur J Dent. 2010; 4: 454-461.

16. Ullah M, Showkat M, Ahmed NU, Islam S, Absar N. Evaluation of Momordica charantia L. fruit extract for analgesic and antiinflammatory activities using in vivo assay. Research Journal of Medical Plant. 2012; 6(3): 236-244. doi: 10.3923/rjmp.2012.236.244

17. Rainsford KD. Ibuprofen: pharmacology, efficacy and safety. Inflammopharmacology. 2009; 17(6): 275-342. doi: 10.1007/s10787-009-0016-x 